\title{
From Syria to the Land Down Under - The Land of Opportunity?
}

\begin{abstract}
Ethnic entrepreneurship has emerged as an economic, societal, and political panacea to the growing number of refugees on the move across the globe. Employing the 2014 World Economic Forum framework, this paper seeks to explore the Australian entrepreneurship ecosystem, to determine whether it is enabling migrants and/or refugees to become entrepreneurs with a focus on Syrian refugees. At its core, the Australian entrepreneurship ecosystem is comparatively strong in terms of human capital, accessible markets, and finance. Even within the three 'core' characteristics of the ecosystem, the Australian ecosystem falls short when examined through the lens of refugee entrepreneurs. Recommendations under the 2014 World Economic Forum framework are made that will assist key stakeholders in developing an entrepreneurial ecosystem.
\end{abstract}

\section{Keywords}

entrepreneurship ecosystem; ethnic entrepreneur; refugee entrepreneur; Australia; World Economic Forum framework

\section{Introduction}

In today's rapidly changing world, countries need enterprising people who have the willingness and ability to take control of their own lives. Entrepreneurs that can turn a vision into reality positively influence the long-term strength of any economy because they are creating the industries of the future. For entrepreneurs to be able to operate, there needs to be an appropriate entrepreneurship ecosystem present for them to do so. A key component of an ecosystem is the entrepreneur and that entrepreneur can be a native entrepreneur or an ethnic/refugee entrepreneur.

Currently there is a nation on the march across South-Eastern Europe. Syrians are leaving their homeland seeking refuge throughout Europe. According to the Red Cross, ${ }^{1} 16$ million Syrians have been displaced since the conflict started 4 years ago. The movement of Syrians out of their own country escalated during 2015 and consequently, Australia announced that it will accept 12,000 refugees from Syria. ${ }^{2}$ This incoming group of educated but resourcepoor Syrians will need to gain employment to properly integrate into Australian life. One possible choice will be the creation of their own business to support themselves and their ethnic community. This leads to the focus of this paper, which is to examine how capable is the current entrepreneurship ecosystem in Australia in sustaining the anticipated refugees from Syria. The methodological approach adopted for this paper involves a critical reflection on the entrepreneurship ecosystem literature, along with a systematic analysis of best practice in Australia, with a focus on ethnic/refugee entrepreneurs. The World Economic Forum's (WEF)

\footnotetext{
${ }^{1}$ Syria Crisis Appeal, Red Cross,

<redcross.org.au/syriacrisis.aspx?gclid=CPT54MLjlsgCFUqWvQodGg4KGA>, visited on 27 September 2015.

${ }^{2}$ A. Henderson, and E. Borrello, 'Australia Confirms Air Strike in Syria, Announces Additional 12,000 Refugee Places', ABC Corporation, 2015, <www.abc.net.au/news/2015-09-09/australia-to-accept-additional-12000syrian-refugees/6760386>, visited on 27 September 2015.
} 
Birdthistle, Flynn \& Rushworth (International Journal of Minority and Group Rights).

2014 entrepreneurship ecosystem model was used as a framework due to its global focus and country analysis, which is appropriate for this study. ${ }^{3}$

\section{Ethnic Entrepreneurship and its Emergence}

Ethnic entrepreneurship has been a field of study in European countries since the late 1980's ${ }^{4}$ though it has its origins in the United States, where the foreign born have been overrepresented in small businesses since the 1880's. Ethnic, minority and immigrant are terms used interchangeably by researchers though there are subtle differences amongst the terms, some authors identify immigrants as recent arrivals in a country ${ }^{5}$, whilst others identify ethnic entrepreneurship as "a set of connections and regular patterns of interaction among people sharing common national background or migration experiences". ${ }^{6}$ The term ethnic does not exclude immigrant or minority groups. Basu and Altinay define minority entrepreneurs as being business owners who do not belong to the majority population. ${ }^{7}$ They further explain that a minority may not (necessarily) be an immigrant and may not share a strong sense of group solidarity with an ethnic group, in terms of a shared history, language, or religion. The variety of definitions indicates the interest in ethnicity and minority entrepreneurship. The broad title ethnic entrepreneur is adopted here as an all-encompassing term.

Refugees form a subset of the ethnic entrepreneur population. While refugees are not necessarily from a different ethnic group to their host country, in practice, they usually are and in the context of Australia, they always have been. It is therefore argued that refugees face similar challenges to ethnic entrepreneurs from different backgrounds, but the barriers are even more significant, given that refugees are likely to suffer a degree of trauma arising from having to flee their home country. Furthermore, they often have no choice about their country of destination and arrive knowing very little about it, compounding the challenge of integration. The term refugee entrepreneur will be used to identify this subset.

So, what motivates ethnic entrepreneurs to establish a venture? Volery in his research identifies that ethnic entrepreneurs establish a business as an "obvious reaction to blocked opportunities in the labour market". ${ }^{8}$ By establishing a business, ethnic entrepreneurs create their own employment and can overcome some of the many barriers they face when they have relocated to another country. Barriers include the perception that ethnic entrepreneurs may lack educational qualifications, that they have limited access to relevant social networks for transmitting information on vacancies, and/or that local employers may simply discriminate

\footnotetext{
${ }^{3}$ M. Drexler, and M. Eltogby, Entrepreneurial Ecosystems around the Globe and Early-Stage Company Growth Dynamics (World Economic Forum, Geneva, 2014).

${ }^{4}$ I. Rath and A. Swagerman, Promoting Ethnic Entrepreneurship in European Cities (Publications Office of the European Union: Luxembourg, 2011).

${ }^{5}$ R. Chaganti, and P. Greene, 'Who are Ethnic Entrepreneurs? A Study of Entrepreneurs' Ethnic Involvement and Business Characteristics', 40:2 Journal of Small Business Management (2002), pp.126-43.

${ }^{6}$ R. Waldinger, H. Aldrich, and R. Ward, Ethnic Entrepreneurs: Immigrant Business in Industrial Societies (Sage, London, 1990), p.3.

${ }^{7}$ A. Basu, and E. Altinay 'The Interaction between Culture and Entrepreneurship in London's Immigrant Businesses', 20 International Small Business Journal (2002) pp.371-393.

${ }^{8}$ T. Volery, (2007) 'Ethnic Entrepreneurship: A theoretical framework', in L.P. Dana (ed), Handbook of Research on Ethnic Minority Entrepreneurship: A Co-Evolutionary View on Resource Management (Edward Elgar, Cheltenham 2007), pp.30.
} 
against them. ${ }^{9,10}$ Desiderio ${ }^{11}$ further supports this by highlighting that "both low-skilled and highly qualified migrants may use entrepreneurship as a strategy to overcome obstacles to successful market integration, be those obstacles to accessing qualified employment or to upward occupational mobility". These definitions are consistent with the concept of necessity entrepreneurship identified by the ongoing Global Entrepreneurship Monitor (GEM) crossnational research. ${ }^{12}$

In welcoming ethnic entrepreneurs to a nation, the host nation needs to be cognisant of the fact that its entrepreneurship ecosystem needs to be tailored for them. A one size fits all approach does not work in this case. It is imperative that the ecosystem is tailored for ethnic entrepreneurs as they will have additional and/or specific issues that native-born entrepreneurs will not have experienced. This is particularly important for refugee entrepreneurs who, as discussed above, face significant additional barriers to entrepreneurial activity. The next section discusses the entrepreneurship ecosystem and then specifically focuses on each pillar in the Australian context.

\section{The Entrepreneurship Ecosystem}

The concept of entrepreneurial ecosystems has recently become a hot topic amongst both policy-makers and academics. According to Stam it has been heralded as a new framework accommodating the transition from an entrepreneurship policy towards a policy for an entrepreneurial economy. ${ }^{13}$ But what is it? The concept itself does not have an agreed definition. For example, Mazzarol ${ }^{14}$ explained it is "as a conceptualisation of an environment in which the right combination of elements helps to foster economic growth through enterprise and innovation". Stam's ${ }^{15}$ definition somewhat reflects Mazzarol's views through proposing "the entrepreneurial ecosystem as a set of interdependent actors and factors coordinated in such a way that they enable productive entrepreneurship". Stam ${ }^{16}$ further highlights that "geographically an ecosystem could be a city, a region, a country and other systems, less strictly defined in space, such as sectors or corporations".

To examine a nation's ecosystem, the World Economic Forums (WEF) model can be applied and this is the lens taken in this paper and it is appropriate due to its the country and global focus. Originally the WEF in 2012 proposed that an ecosystem for entrepreneurship comprised of seven pillars (support mechanism, funding and finance, human capital, education and training, regulatory framework and infrastructure, culture, and markets). Within 12 months the WEF redeveloped this ecosystem and added another pillar to it: Universities as Catalysts. ${ }^{17}$ The presence of these pillars does not guarantee an effective ecosystem. It is the targeted nature of these pillars and their complimentary interactions that determines whether they are fit for

\footnotetext{
${ }^{9}$ J. Rath, 'Ethnic Entrepreneurship: Concept Paper', European Commission 2010

$<$ www.eurofound.europa.eu/publications/htmlfiles/ef1039.htm>, visited on 3 October 2011.

${ }^{10}$ N. Birdthistle, An examination of Ethnic Entrepreneurship in the Mid-west region of Ireland (Doras Luimni, Ireland 2012).

${ }^{11}$ M.V. Desiderio, Policies to support immigrant entrepreneurship (Migration Policy Institute, Washington, DC, 2014), p.2.

${ }^{12}$ P. Davidsson, P. Steffens, and M. Stuetzer, Global Entrepreneurship Monitor Report: National

Entrepreneurial Assessment for Australia (QUT Publications, Australia, 2012).

${ }^{13}$ E. Stam, Entrepreneurial Ecosystems and Regional Policy: A Sympathetic Critique (U.S.E. Discussion Paper Series, nr:15-07, 2015).

${ }^{14}$ T. Mazzarol, 'Entrepreneurial Ecosystems and the Role of Regulation and Infrastructure', The Conversation, $<$ theconversation.com/entrepreneurialecosystemsandtheroleofregulationandinfrastructure 37030 $>$, visited on 10 August 2015.

${ }^{15}$ Stam supra note 13, p.5.

16 Ibid., p.5.

${ }^{17}$ Drexler and Eltogby supra note 3.
} 
Birdthistle, Flynn \& Rushworth (International Journal of Minority and Group Rights).

purpose. Figure 1 identifies each pillar of an entrepreneurial ecosystem, which forms the foundation for this paper.

$<<$ Figure 1 here $>>$

\subsection{Australia's Ecosystem for Entrepreneurs}

For this paper, the level of analysis is on a country basis i.e. Australia. The US is included here as the benchmark with high scores across all pillars. The UK and Ireland are included as European countries that have historical links and institutional similarities to Australia. Pakistan also has historical links to the UK and a sizeable Chinese ethnic community. Singapore has two minority ethnic groups Malays and Indians, and was once a British colony. Mexico is included here, as in common with Australia, it is a member of the Asia-Pacific Economic Cooperation, among others and has indigenous peoples, recognising a total of 56 different groups. Not all countries have strengths when it comes to the pillars of the entrepreneurship ecosystem and Table 1 provides evidence of this for a given set of countries. ${ }^{18}$ The higher per cent pillar score per country indicates the nation that readily provided the pillar content and the lower per cent indicates the opposite.

When compared overall, Australia fares poorly with an average score of 53 per cent for the eight pillars, with only Pakistan and Mexico scoring lower. The US not surprisingly, comes in first in six of the eight pillars with an average score of 77 per cent. The UK and Singapore have average scores that place them $2^{\text {nd }}$ and $3^{\text {rd }}$. What is evident is Australia has no pillar in the 90 per cent range, only two pillars in the 70 per cent range with the majority falling between 50 per cent and 20 per cent. It has been reported that entrepreneurs cite the first three pillars (human capital workforce, accessible markets, and funding \& finance) as of "pivotal importance". ${ }^{19} \mathrm{On}$ these three pillars, Australia rates third behind the US and the UK. This suggests that Australia has a strong core entrepreneurial ecosystem. However, an analysis of the remaining five pillars highlights weaknesses in the Australian ecosystem, which places it $5^{\text {th }}$ (39 per cent) after the US, UK, Singapore, and Ireland and only marginally ahead of Mexico.

$<<$ TABLE 1 here $>>$

The following section will explore, from an Australian perspective, each of the pillars in the context of supporting refugee entrepreneurs.

\subsubsection{Human Capital and Workforce}

Many studies have identified a positive relationship between an entrepreneur's preceding work experience as an employee and their business development. ${ }^{20,21}$ Previous employment experience in the host country increases immigrant's knowledge of the business environment, leading to better access to information, human capital, and funding from formal institutions. ${ }^{22}$

\footnotetext{
${ }^{18}$ Ibid.

${ }^{19}$ Ibid., p.4.

${ }^{20}$ N. Bosma, M.V. Praag, R., Thurik, and G.D. Wit, 'The Value of Human and Social Capital Investments for the Business Performance of Start-ups', 23:3 Small Business Economics (2004), pp.227-236.

${ }^{21}$ E. Chrysostome, 'The Success Factors of Necessity Immigrant Entrepreneurs: In Search of a Model', 52:2 Thunderbird International Business Review (2010), pp. 137-152.

${ }^{22}$ A. Basu, B. Yeung, and M. Casson, (eds), The Oxford Handbook of Entrepreneurship (Oxford Handbooks Online, UK, 2008).
} 
Supportive of this, Deakins and Whittam purport that "the formation of business ideas and the ability to establish a successful business will be affected by the entrepreneur's experience, training, education and skill development". ${ }^{23}$ Chaganti and Greene suggest that less experienced entrepreneurs have reduced opportunities for success and tend to concentrate exclusively on ethnic markets. ${ }^{24} \mathrm{~A}$ lack of managerial experience and poor business skills are confirmed as key reasons for the failure or poor performance of ethnic businesses. ${ }^{25}$ This suggests that opportunities to enter the workforce generally should be part of the support system for refugee entrepreneurs and more specifically for the incoming Syrian refugee entrepreneurs, to get an understanding for how business is done in Australia before starting out on their own.

Australia's high ranking may offer advantages for the integration of highly educated refugee entrepreneurs (provided their qualifications are recognised in Australia). However, it may present an additional barrier for those with limited education as entering a relatively highly-educated country, coupled with language barriers, increases their disadvantage in entering either the workforce or self-employment. While Australia offers some incentives to high-calibre business migrants (such as the Business Talent Visa for high-calibre business owners or people who have sourced venture capital ${ }^{26}$, or to migrants willing to work in regional or rural areas (the Regional Established Business in Australia visa), this offers no benefit to refugees who already hold permanent residency status. Furthermore, the Refugee Council of Australia finds that refugees face barriers to entering the local workforce, thus reducing their opportunities to gain local work experience to help them integrate.

\subsubsection{Accessible Markets}

Ethnic entrepreneurs mainly cater for customers in their own [ethnic] enclave and researchers have stated that ethnic entrepreneurs need to be "encouraged to break out of these captive markets". ${ }^{27}$ To get out of this mind-set, ethnic entrepreneurs need to adopt marketing methods to attract customers from all communities. The capacity to expand into markets beyond their limited enclave is linked to the skill level of the ethnic entrepreneur. ${ }^{28}$ Previous waves of refugees entering Australia have indeed established their own ethnic enclaves. For example, the 1970s/80s influx of Vietnamese 'boat people' established vibrant communities in major cities (Cabramatta in Sydney, Richmond and Footscray in Melbourne). As well as catering to their local ethnic community, they have integrated into the general community through food businesses which make Sydney and Melbourne world-renowned for varied, authentic, and affordable cuisine from a wide variety of cultures. Saunders identified such enclaves as arrival cities, which are clusters of migrants (internal or from overseas) on the outskirts of large cities. ${ }^{29}$ Though often regarded negatively as ghettos, Saunders argued that they were in fact the foundation of thriving entrepreneurial communities, founded on the social capital developed among their inhabitants.

\footnotetext{
${ }^{23}$ D. Deakins, and G. Whittam, 'Business start-up: theory, practice and policy', in S. Carter, and D. JonesEvans, (eds.) Enterprise and Small Business: Principles, Practice and Policy (Financial Times Prentice-Hall, London, 2000), p.116.

${ }^{24}$ Chaganti and Greene supra note 5.

${ }^{25}$ Birdthistle, supra note 10.

${ }^{26}$ J. Collins, 'Immigrant entrepreneurs in Australia: Regulations and responses', 3 Migrações (2008), pp.49-59.

${ }^{27}$ Rath and Swagerman, supra note 4, p.54.

${ }^{28}$ Chaganti and Greene, supra note 5.

${ }^{29}$ D. Saunders, Arrival City: The Final Migration and our Next World (Knopf, Canada, 2011).
} 
Liberal MP Philip Ruddock, quoted on ABC, has warned against the ghettoising of the Syrian refugees. ${ }^{30} \mathrm{He}$ went on to say that locating Syrian refugees within existing ethnic communities can provide a solid foundation of social supports, bolstered by the appropriate government integration initiatives. The Australian government has no specific incentives for enabling ethnic entrepreneurs to access alternative markets, but it does assist entrepreneurs in general in developing an export strategy through providing an Export Market Development Grant, ${ }^{31}$ which ethnic/refugee entrepreneurs can also avail of.

\subsubsection{Funding and Finance}

Accessing finance, especially in today's economic environment, is a major challenge, particularly for ethnic entrepreneurs who are now faced with a completely different financial environment to that she/he experienced in their home country. According to the OECD/European Commission ${ }^{32}$ ethnic entrepreneurs use informal or community based funding mechanisms to secure financing. These sources are often limited to relatively low amounts therefore they tend to downside their business plans to take this into account. Therefore, the European Commission established the Competitiveness and Innovation Framework Program (CIP). Microcredits are small bank loans to assist people who have no collateral and/or who have no access to common bank credit. This scheme is quite new to Europe, since it was first propagated in regions such as India and South America. The European Commission sought to improve the availability of microloans for small businesses and for socially excluded people who wish to become self-employed, such as ethnic entrepreneurs. The Joint Action to Support Microfinance Institutions (JASMINE) was therefore founded and has been extended to operate from 2014-2020. Microcredit schemes have become widespread throughout the EU and EEA. ${ }^{33}$

Australia provides a multitude of government grants which may be provided at federal, state/territory, or local government level, through a range of different government portfolios. Keeping track of them though is a challenge and for entrepreneurs identifying those relevant to their own business presents a significant challenge. Some grants potentially useful to refugee entrepreneurs include the No Interest Micro-business loan grant in Tasmania, which provides an interest-free loan for the development of a business idea into a practical proposal. However, there are eligibility criteria such as the need to have a Health Care Card and have a completed business plan. ${ }^{34}$ Therefore, ethnic/refugee entrepreneurs, and more specifically the Syrian refugees who are coming to Australia, will have to wait some time before availing of this support until they meet the eligibly criteria set. In other cases, there are restrictions based on the minimum threshold or operating expenditure threshold i.e. AUD\$750,000 for SME businesses, which is prohibitive to newly established businesses and even more so for Syrian

\footnotetext{
${ }^{30}$ D. Conifer, F. Keany, and A. Henderson, 'Syrian Refugees', ABC Corporation 2015, <www.abc.net.au/news/2015-09-17/most-syrian-refugees-expected-to-resettle-in-sydney-melbourne/6782012, visited on 27 October 2015.

${ }^{31}$ P. Morle, Z. Kitschke, A. Jones, and J. Tanchel, 'Silicon Beach Building Momentum: A study of the Australian Startup Ecosystem', <www2.deloitte.com/au/en/pages/technology-media-andtelecommunications/articles/silicon-beach-study-australian-startup-ecosystem.html>, visited on 22 October 2015.

32 OECD/European Commission, The Missing Entrepreneurs: Policies for Inclusive Entrepreneurship in Europe (OECD Publishing, Brussels 2014) http://dx.doi.org/10.1787/9789264213593-en, p.114.

${ }^{33}$ European Microfinance Network, 'About Us, European Microfinance Network', <www.europeanmicrofinance.org/index 2 _en.php>, visited on 3 December 2011.

${ }^{34}$ Business, 'Australian Government', 2015 <www.business.gov.au/Pages/default.aspx>, visited on 20 October 2015(a)
} 
refugees who often come to a country with only the clothes on their backs. Collins ${ }^{35}$ identifies the New Enterprise Incentive Scheme (NEIS) as a federal scheme that ethnic entrepreneurs can avail of, thus this scheme should be communicated to refugee entrepreneurs on entry to the country. Overall, it was difficult to find a targeted grant/funding scheme for ethnic entrepreneurs at the federal level. Australia has been found to lag behind other innovation driven economies in terms of government programmes. ${ }^{36}$ For refugees, arriving with no savings and no assets, access to even the smallest seed funding presents significant challenges. Microfinance addresses this need, but is underdeveloped in Australia. The Department of Social Services lists a very limited number of microfinance and matched savings initiatives, only one of which - Good Shepherd Microfinance - appears to be traditional microfinance. ${ }^{37}$

\subsubsection{Support Systems}

A significant obstacle for any new entrepreneur is their lack of familiarity with regulations and procedures when starting their business. Ethnic entrepreneurs are, however, particularly disadvantaged in this regard due to lower education levels and language barriers. Occasionally, measures provide material assistance, for example incubation units/programmes. One would question how well this measure is being achieved as Rath and Swagerman found that a challenge that many ethnic entrepreneurs face is finding a location, such as office space, manufacturing space and/or a shop ${ }^{38}$. In relation to networking, Rath and Swagerman identify "initiatives to improve connections between SMEs may be generic, targeting entrepreneurs regardless of origin". 39

The US, UK and Pakistan rank the highest when it comes to support systems with Australia coming fourth. This pillar involves the networks of peers, mentors and professional advisors that surround entrepreneurs. Incubators and accelerators are a good indicator of support systems; since they seek to concentrate these in a single location. The rationale for incubators and accelerators is to kick-start high growth potential start-ups, however some doubt has been expressed as to how effective this model is in the absence of a robust venture capital sector to provide follow-up funding on graduation. ${ }^{40}$ Kinner supports this by identifying that the availability of venture capital is a measure of how supportive a country's ecosystem is. He found that Australia barely registers on the radar when comparing domestic venture capital investment with that of its global counterparts. ${ }^{41}$

It is questionable whether many of the incubators and accelerators in Australia would offer useful support to refugee entrepreneurs, except for those who speak English and have an entrepreneurial background. A recent discussion paper highlights that the accelerator model does not suit all businesses, particularly those that do not require significant seed capital, but nevertheless they can benefit from support during the vulnerable start-up stage. ${ }^{42}$ Incubators, often known as enterprise centres or hubs are still commonly found in Australia, usually

\footnotetext{
${ }^{35}$ Collins, supra note 26.

${ }^{36}$ Davidsson et al., supra note 12, p.20.

${ }^{37}$ Microfinance and matched savings initiatives, Department of Social Services, 2015, <www.dss.gov.au/ourresponsibilities/communities-and-vulnerable-people/programs-services/commonwealth-financial-counsellingcfc/microfinance-and-matched-savings-initiatives>, visited on 2 November 2015.

${ }^{38}$ Rath and Swagerman, supra note 4.

${ }^{39}$ Ibid, p.56.

${ }^{40}$ Mazzarol supra note 14.

${ }^{41}$ C. Kinner, Boosting High-Impact Entrepreneurship in Australia: A role for Universities (Australian Government: Office of the Chief Scientist, 2015).

42 J. Webb, 'Trends and Directions in Small Business Innovation and Incubation', $<$ businessincubation.com.au/wp-content/uploads/WebsiteTrendsDirections-V2.pdf $>$, visited on 10 October 2015 .
} 
supported by local government, providing working spaces, advice, mentoring and networking for slower-growing, organically financed start-ups. Ethnic communities support their members with education and mentoring through a range of NGOs, many of them affiliated with the Federation of Ethnic Community Councils of Australia (FECCA). However, these NGOs themselves are under threat through reduction or removal of the small grants on which they rely, such as the Settlement Grants Programme (becoming harder to access), the Migrant Communities Employment Fund and the Building Multicultural Communities Fund (both recently discontinued). ${ }^{43}$ Finally, the NEIS program (referred to in section 3.1.3) provides ongoing mentoring as well as other supports.

\subsubsection{Regulatory Framework and Infrastructure}

To increase the success of entrepreneurial measures, appropriate policies and programmes should be developed to spread the entrepreneurial culture and to encourage people to be entrepreneurs. According to Molenaar et al., ${ }^{44}$ and the European Commission's ${ }^{45}$ study of ethnic entrepreneurship policies in Europe they could identify 146 policy measures which offered services that led to the strengthening of human, social, and/or financial resources which enables the ethnic entrepreneur to be empowered. The focus of these policies is on enhancing the human capital of entrepreneurs through training, counselling, and information services. They found that interventions fostering social networking explicitly are small, however many promote networking implicitly instead. Fewer measures focus on providing financial services, but in fact, many programmes facilitate access to finance by strengthening the entrepreneur's skills and knowledge.

Australia scored 54 per cent when it came to Regulatory framework and Infrastructure and only two per cent greater than Mexico. According to (then) Treasury officials Kukoc and Regan, weaknesses of the Australian government "are the absence of indicators and accurate, internationally comparable data that reflects the innovative nature of entrepreneurship and distinguishes it from ordinary business activities. Furthermore, without such data it is difficult to draw firm conclusions about the true level of entrepreneurial activity in Australia or any other country or improve the quality of public policy initiatives aimed at supporting this activity". ${ }^{46}$ Kinner $^{47}$ identifies that Australia is the only country in the OECD that does not have a science and innovation strategy and "lacks a consistent narrative about how the country will transition to a knowledge-intensive economy".

The World Economic Forum (WEF) identified that Australia's infrastructure ranked $18^{\text {th }}$ out of 148 nations, an improvement on its ranking of $20^{\text {th }}$ in $2012 .{ }^{48}$ However, it highlighted that Australia lags behind the world's best practice (i.e. Hong Kong - ranked $1^{\text {st; }}$ Singapore $2^{\text {nd. }}$; Germany $3^{\text {rd }}$ ). When defining a well-developed infrastructure Schwab ${ }^{49}$ broke this down to

\footnotetext{
${ }^{43}$ Fact Sheet 4: Funding and Capacity Building for New and Emerging Community Organisations, FECCA, 2014a, <fecca.org.au/wp-content/uploads/2015/06/factsheet4_access-to-funding-for-new-and-emergingcommunity-organisations.pdf $>$, visited on 27 October 2015.

${ }^{44}$ K. Molenaar, I. Rath, G, Ribbink, M. van Niekerk, J. Vonk, W. Gondrie, Promoting Ethnic Minority Entrepreneurship in Europe (Triodos Facet, P.O., The Netherlands, 2008).

${ }^{45}$ European Commission, The Young, Women, Ethnic Minority and Co-Entrepreneurs Report, (Centre for Enterprise and Economic Development Research Middlesex University Business School, UK 2000).

${ }^{46}$ K. Kukoc, and D. Regan, 'Measuring Entrepreneurship', Economic Roundup (2008),

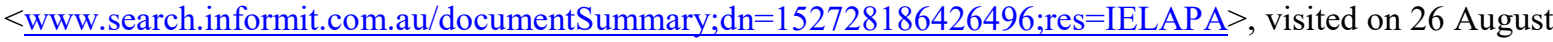
2017 , p.6.

${ }^{47}$ Kinner, supra note 41, p.61.

${ }^{48}$ K. Schwab, The Global Competitiveness Report 2013-2014: Full Data Edition (World Economic Forum, Switzerland, 2013).

${ }^{49}$ Ibid, p.5.
} 
mean a well-developed transport and communications network; an effective mode of transport including quality of roads, ports, and air transport; unimpeded businesses and factories in terms of electricity supplies and a solid extensive telecommunications network. Table 2 below provides a snapshot of the infrastructure and regulatory framework for Australia.

\section{$<<$ TABLE 2 here $>>$}

In relation to Australia's infrastructure there is room for improvement. When compared to Singapore and New Zealand in terms of cost of trading across borders, paying taxes and registering property, Australia performs badly. When compared to the OECD average, Australia's compliance costs for trading across borders were found to be worse. For securing export permits it takes five separate documents and for imports seven documents. Mazzarol ${ }^{50}$ also highlights that "the average cost per container shipped from Australia was around US1,150 and US1,170 per container for imports". This compared to US440 per container in Singapore and US870 (export) and US825 (import) for New Zealand. Additionally, the length of time it takes to import/export goods is double that when compared to Singapore (8-9 days compared to 4). Therefore, for ethnic entrepreneurs who import goods from their home nation, this is an expensive and lengthy business activity for them.

Though not the highest in the world, Australia's company tax rates are around 30 per cent when the OECD average is 25.6 per cent. Mazzarol ${ }^{51}$ highlights that Australian businesses pay 47 per cent of annual profit in taxes, it takes some 105 hours per year to complete and it takes 11 separate payments. In Singapore, its significantly less i.e. 17 per cent in taxes, 82 hours per annum to complete and only 5 taxes are paid each year, therefore there are 'like with like' nations that Australia could learn from. In relation to legislation, Collins ${ }^{52}$ found that many ethnic entrepreneurs in Australia who contributed to his findings complained of the difficulty of having to work their way around the bureaucratic maze of legislation, red tape and policy developments that impacted on their business.

The Australian tax system does offer some incentives to small and new businesses including: reduced tax rates whether incorporated or sole trader, immediate asset deductions up to AUS20,000, and of professional costs associated with startup. ${ }^{53}$ In addition, SMEs with turnover under AUS2m can operate cash rather than accrual accounting, which is more aligned to the viability of startups and any SMEs with a lengthy cash conversion cycle.

\subsubsection{Education and Training}

Allison et al., ${ }^{54}$ found that throughout Europe the approaches to entrepreneurship teaching and learning are diverse and that "more sophisticated, fully integrated approaches are becoming embedded in the student experience, in particular involving them in real-life situations and market requests and developments faced by industry". Furthermore, they highlight that "interdisciplinary and multidisciplinary experiences are important for students engaged in entrepreneurship and innovation". Having migrant students enrolled in university has proven to be beneficial to a nation. For example, Hunt and Gauthier-Loiselle ${ }^{55}$ found that a 1.3 per

\footnotetext{
${ }^{50}$ Mazzarol, supra note 14, p.4.

${ }^{51}$ Ibid.

${ }^{52}$ Collins, supra note 26, p.56.

53 Jobs and Small Business Package, Australian Government, 2015, <www.business.gov.au/smallbusiness/Pages/jobs-and-small-business-package.aspx>, visited on 2 November 2015(b).

${ }^{54}$ R. Allison, Z. Javorka, A. Krcal, and X. Potau, 6th University Business Forum Report (European Commission, Brussels, 2015), p.3.

55 J. Hunt, and M. Gauthier-Loiselle, 'How much does Immigration Boost Innovation?' NBER Working paper series, (2008) no.14312.
} 
cent increase in the migrant population of college graduates in science and engineering courses caused a 20 per cent increase in patents per capita.

Once accepted as refugees to Australia, refugees have access to normal welfare programmes, including unemployment benefit, making them eligible for NEIS, delivered through the national network of Technical and Further Education (TAFE) colleges and aims to move participants from unemployment to self-employment. Participants undertake the Certificate IV in Small Business Management course (3 months) and receive ongoing income for the next 9 months. They also receive 12 months of business mentoring.

According to Oliveira and Rath ${ }^{56}$, ethnic entrepreneurs are often associated with a wide array of problems, notably a general lack of business management skills and competences, and often also a poor grasp of the host country's language. Clearly refugees need to have adequate English and basic education to complete training successfully. Such education is available in Australia, but there are difficulties with access to it as highlighted by FECCA $^{57}$ who has identified many barriers facing new communities attempting to integrate into education and employment and these include: poor English skills, lack of local networks, vulnerability due to trauma, low levels of education/training; non-recognition of prior education/experience, and dealing with unfamiliar government structures, discrimination.

\subsubsection{Universities as Catalysts}

This pillar is the newly added dimension to the entrepreneurial ecosystem. Though entrepreneurship education offerings have grown significantly globally in the past decade, this trend is not evident in Australia ${ }^{58}$ and this is possibly reflective of the low score attributed to it (38 per cent). Currently two Australian universities offer a Masters in Entrepreneurship, with an additional 13 postgraduate programmes offering at least 50 per cent of their content in entrepreneurship. ${ }^{59}$ However, to gain entry onto these programmes requires previous work experience and a recognised undergraduate/professional qualification. Endowed chairs, common in the US are largely absent in Australia. ${ }^{60}$ Furthermore, Kinner ${ }^{61}$ explicitly states that Australia's startup ecosystem is immature and that it is 'important that educational programmes focus on imparting core skills'. Additionally, Kinner ${ }^{62}$ highlights that 'entrepreneurship education in most Australian universities is delivered by academics with limited first-hand experience of entrepreneurship'. He suggests that to engender a culture of entrepreneurship on campus 'it is essential that senior leaders actively promote the cause and engage the university community in a dialogue about the role of entrepreneurship in the university,. ${ }^{63}$

Refugee entrepreneurs are likely to encounter significant barriers accessing even those university programmes that exist. Swinburne University of Technology in Melbourne, has recognised this challenge and has engaged in dialogue with the Refugee Council to discuss the Syrian refugees that are coming to the region soon. It has designed a 'Taster' programme that will introduce the vocational courses it has available to refugees and to other ethnic groups. To make members of the ethnic community feel welcome, Swinburne University has developed a

\footnotetext{
${ }^{56}$ C.R. Oliveira, and J. Rath, 'Migraçốes', 3 Journal of the Portuguese Immigration, (2008), p.82.

${ }^{57}$ Fact Sheet 1: Introduction to New and Emerging Communities, FECCA, 2014b, <fecca.org.au/wpcontent/uploads/2015/06/factsheet1_introduction-to-new-and-emerging-communities.pdf $>$, visited on 27 October 2015.

${ }^{58}$ A. Maritz, C. Jones, and C. Schwetzer, 'The Status of Entrepreneurship Education in Australian Universities,' 57:8/9, Education + Training (2015) pp.1020-1035 http://dx.doi.org/10.1108/EO-04-2015-0026.

${ }^{59}$ Ibid.

${ }^{60}$ Kinner, supra note 41.

${ }^{61}$ Ibid, p. 27.

${ }^{62}$ Ibid, p. 12.

${ }^{63}$ Ibid, p. 47.
} 
'Welcome Tree' which has words of welcome written in a variety of languages from members of the wider community. Furthermore, Victoria University offers the John Byrne Scholarship for Refugees, which aims to support a recent refugee who is undertaking TAFE studies at the university. The Ignite programme, an initiative of Migrant Resource Centres in New South Wales has taken 129 refugee entrepreneurs from 25 different countries. Programmes like this and Stepping Stones are being hailed as a key component of Australia's response to the integration of the anticipated Syrian refugees.

\subsubsection{Cultural support}

According to Singer et al., ${ }^{64}$ if a country wants to be more proactive in developing an entrepreneurial culture, it is relevant to implement consistent policies and programmes on restructuring the capability of the education system toward providing entrepreneurial competences as a kind of transversal skill for everyone. The UK government has recognised the importance of this by dedicating one day in the school calendar so that all secondary school children do 'enterprise' for the day. The European Commission supports the European Day of the Entrepreneur which includes activities for youth, public, politicians and it is a tool that is used to promote entrepreneurship to create growth in jobs. As mentioned previously, Australia is the only country in the OECD that does not have a science and innovation strategy, however moves are afoot to change this. In 2015, the Australian government proposed to refocus its industry policy to drive entrepreneurship and innovation. ${ }^{65}$

Singer et al., ${ }^{66}$ found that on a global basis, African and North American economies display a greater entrepreneurial culture when compared to EU economies. They attributed this to the value of high status attributed to successful entrepreneurs found in these two economies and which was additionally supported by high media attention for entrepreneurship. They found that EU economies showed the lowest social values towards entrepreneurship in terms of (i) being a desirable career choice, (ii) being associated with high social status and (iii) being the focus of positive media attention. An example of positive media attention is the 'Ethnic Entrepreneur of the Year Awards' in Ireland, which aims to reward members of ethnic minority groups for their work in establishing businesses and social projects throughout the country and has been in operation since 2007. This awards programme gets national airtime on the television, newspaper, and radio.

Australia's low rating of 29 per cent on Cultural Support is surprising, placing it well behind culturally similar countries such as Ireland (42 per cent) and England (40 per cent) and only just ahead of Pakistan ( 25 per cent) and Mexico (22 per cent). Furthermore, it is at odds with Davidsson et al. 's ${ }^{67}$ GEM findings which indicated that 53 per cent of Australians thought entrepreneurship was a desirable career choice, 67 per cent felt successful entrepreneurs had high status and 73 per cent found media attention to entrepreneurship positive. The contra position may be explained by Australia's attachment to the 'tall poppy syndrome', whereby the 'very successful' may be regarded with envy and suspicion and there is enjoyment at seeing them fall from grace. It is unlikely, however, that portrayals of entrepreneurs in the media have much influence on refugee entrepreneurs, as they fall into the category of 'necessity entrepreneurs'. ${ }^{68}$

\footnotetext{
${ }^{64}$ S. Singer, J.E. Amoros, and D. Moska, Global Entrepreneurship Monitor Report 2014 Global Report (Global Entrepreneurship Research Association, London 2014).

65 Australian Government, supra note 34.

${ }^{66}$ Singer, supra note 64, p.12.

${ }^{67}$ Davidsson et al., supra note 12.

${ }^{68}$ P. Reynolds, S. Camp, W. Bygrave, E. Autio, and M. Hay, Global Entrepreneurship Monitor 2001 Executive Report (Babson College and London Business School, Boston, 2002) p.56.
} 


\section{Conclusion and Recommendations}

The conclusions that can be drawn from this paper is that; at its core, Australia has the foundations of a positive entrepreneurship ecosystem i.e. strong human capital workforce, accessible markets and funding and finance. However, when these three pillars are specifically examined for ethnic/refugee entrepreneurs, the paucity of services and supports are apparent. In relation to the remaining five pillars, the weakness of this sub-group of pillars drags the core group down from a ranking of $3^{\text {rd }}$ place (behind USA and UK) to $5^{\text {th }}$ place. Clearly, concentrating on ameliorating the weak features of these pillars will have the effect of improving the positive potential for all Australian-based entrepreneurs, irrespective of nationality/ethnicity. Therefore, Australia needs to be more aware of its failings in terms of its mentoring and advisory supports, it needs to be even more pro-(small) business; it needs more entrepreneurship training and both more widespread and more accessible University programmes. Overall, we conclude that the evidence suggests that the Australian entrepreneurial ecosystem for refugee entrepreneurs is not fit for purpose. Using the WEF pillars, the following are our recommendations to foster an ethnic/refugee entrepreneurship ecosystem in Australia:

\section{Pillar 1: Human Capital \& Workforce:}

- Support ethnic/refugee community organizations to mentor ethnic entrepreneurs with no prior business background by matching them with experienced entrepreneurs.

- Expand the visa system to target STEM students for undergraduate and postgraduate programmes. There is evidence to show that with an increase in the migrant population in science and engineering courses leads to a reciprocal increase in patents per capita.

\section{Pillar 2: Accessible Markets}

- To minimise the ghettoising of refugees, consider the supports that the community can provide along with the necessary government supports. For example, there is an historical symbiotic relationship between the Lebanese community and the Syrian community.

- Marketing training programmes specifically for ethnic/refugee entrepreneurs should be made available to help them expand beyond their own ethnic community.

Pillar 3: Funding and Finance

- Increase the availability of microfinance, to begin with, aiming to match the relatively widespread availability in Europe and other regions. This scheme could be linked to mandatory training on the regulatory and tax regime in Australia.

- An overhaul/review of the funding and finance schemes needs to be undertaken to ensure that all stages of business growth are catered for and that the programmes are much more inclusive as there are currently restrictions on size and turnover.

- Provide low level funding where the bank acts as guarantor.

Pillar 4: Support systems

- Increased support for connecting existing communities and organizations through umbrella bodies such as RCOA and FECCA and the network of Migrant Resource Centres. For example, local or state government funding for events that would bring the RE community and their supporters together.

- Targeted advice, in multiple languages is required.

- Raising awareness of RE activity and its contribution to economic and social capital, in order to attract volunteer advisers and mentors, and to encourage established organizations to find ways to work with RE businesses (for example at the second author's local primary school a group of Somali refugee women provide cooked meals three days a week).

Pillar 5: Regulatory Framework \& Infrastructure

- In the proposed 2015 redesign of the Industry policy it should be explicit that data is gathered on a yearly basis to enable global comparisons to be conducted.

- Streamline the tax compliance bureaucracy and the bureaucracy around importing and exporting through the investment in IT systems and hiring more compliance officers.

- Offer tax credits/incentives to hire ethnic minorities.

Pillar 6: Education \& Training

- Recent refugees should be supported in their endeavours to educate themselves regarding language skill development and programmes about integration into Australian society. 
Birdthistle, Flynn \& Rushworth (International Journal of Minority and Group Rights).

- Review the Vocational Training education uptake and explore ways to reduce the barriers to this important pillar.

Pillar 7: Universities as Catalysts

- Embed within the curriculum a focus on ethnic entrepreneurship.

- Devise a transition programme that will help refugees to access higher education.

- Encourage senior leaders to debate the issue of entrepreneurship.

Pillar 8: Cultural support

- Make better use of social media to promote the positive aspects of owning one's own business and/or being an ethnic entrepreneur and how they contribute positive to society.

- Produce a TV series that is similar to SBS's highly successful series 'Go Back To Where You Came From' and have the programme focus on local and ethnic entrepreneurs.

Furthermore, we suggest that one of the best ways to foster a vibrant refugee entrepreneurship community is to nurture it with many types of events: workshops, meet-ups, and events such as microbusiness Startup Weekends. These events are powerful because it is critical that refugee entrepreneurs meet each other face-to-face, form bonds, share tips and challenges, and feel the support and camaraderie of their fellow refugee entrepreneurs on their journey. Having a social support structure composed of other refugee entrepreneurs who can empathize and commiserate through the vicissitudes of the business startup journey is critical for the success of startups, especially in a newly forming refugee entrepreneurship ecosystem. ${ }^{69}$

There are however, promising signs of the development of systematic capability in supporting ethnic/refugee entrepreneurial activity. At grassroots level, small or micro NGOs mostly conduct this; supported by government grants, donations, and community volunteers. The Refugee Council of Australia acts as an umbrella organization supporting its members. Unfortunately, these organizations are themselves struggling to survive due to dwindling government grants and increasing bureaucracy to obtaining them. ${ }^{70}$ While refugee entrepreneurship development programmes are always likely to be driven by a passionate and capable few, governments and the corporate sector could do more to support them. The entrepreneurial people behind such programmes are usually highly skilled at networking, finding resources and making the best use of them. But they are necessarily limited in their impact by being dependent on their own time, energy, and personal networks. Government programmes and corporate partners can provide essential resources to help refugee entrepreneurship facilitators such as Ignite's Violet Roumeliotis to scale up their operations.

In summary, the objective of this paper was to determine how supportive the Australian entrepreneurial ecosystem will be to support the incoming Syrian refugee entrepreneurs. By employing the WEF model, we demonstrate that while the Australian ecosystem is in part world class, there are features that need to be ameliorated through targeted policy initiatives and this paper proposed some recommendations to develop the entrepreneurial ecosystem in Australia.

\footnotetext{
${ }^{69}$ The global start-up ecosystem ranking, Compass, 2015, <//startup-ecosystem.compass.co/ser2015/> visited on 12 October 2015, p.10.

${ }^{70}$ FECCA, supra note 57.
} 